\title{
Well Log Petrophysical Analysis and Fluid Characterization of Reservoirs, Rio Del Rey Basin, Cameroon (West African Margin, Gulf of Guinea)
}

\author{
Joseph Bertrand Iboum Kissaaka ${ }^{1}$, Ahmed Salim Mopa Moulaye ${ }^{2}$, Paul Gustave Fowe Kwetche ${ }^{3}$, Francois Mvondo \\ Owono ${ }^{1}$, Marie Joseph Ntamak-Nida ${ }^{1}$ \\ ${ }^{1}$ Department of Earth sciences, Faculty of Sciences, University of Douala, PO. BOX 24157 Douala, Cameroon \\ ${ }^{2}$ Petromines, Faculty of Sciences, University of Douala, PO. BOX 24157 Douala, Cameroon \\ ${ }^{3}$ Institute of Fisheries and Aquatic Sciences, University of Douala, Yabassi, PO. BOX 7236 Douala, Cameroon \\ Correspondence : Joseph Bertrand Iboum Kissaaka, Department of Earth sciences, Faculty of Sciences, University of \\ Douala, PO. BOX 24157 Douala, Cameroon
}

Received: July 30, 2020

Accepted: September 2, 2020

Online Published: September 13, 2020

doi:10.5539/esr.v10n1p1

URL: https://doi.org/10.5539/esr.v10n1p1

\begin{abstract}
The quick-look and gas chromatography analyses were used for formation evaluation of four depth intervals in a well (well A) located within the offshore of the Rio Del Rey basin. The results show 3 water reservoirs (R1 to R3) and 1 hydrocarbon reservoir (R4). The quick-look reveals that the hydrocarbon (oil and gas) reservoir is a shaley sandstone or a radioactive sandstone located between 4898-4932 Mmd which is filled by oil and gas and with a good porosity. The chromatographic gas ratio analysis reveals that the hydrocarbon reservoir is filled by a productive gas which may be a wet gas. The result provided by the gas chromatography is a false result probably due to its limitation which is that the hydrocarbon component must exist at the gaseous phase (C1-C5) to be detected and analyzed. The gas chromatography based its analysis only in the $\mathrm{C} 1$ to $\mathrm{C} 5$ range, in oil we have from $\mathrm{C} 1$ to $\mathrm{C} 8$.
\end{abstract}

Keywords: quick-look analysis, gas chromatography analysis, oil, gas, shaley sandstone

\section{Introduction}

Rio Del Rey basin (RDR) is one of the petroliferous sedimentary basins lining the coast of West Africa. The RDR basin represents the south-eastern extension of the Niger delta which is a prolific hydrocarbon province situated in Gulf of Guinea (Fig. 1). Many Geological studies were already made with the logging data (Kabbabe, 2008; Noudjo et al., 2018) but few combined quick-look and chromatographic gas ratio analyses to evaluate a geological formation. The objective of this study is to identify possible reservoir with the potential to contain hydrocarbons, delineate hydrocarbon type (oil/gas), and evaluate the hydrocarbon quality and productivity.

\section{Geological Setting}

Rio del Rey basin is a divergent passive margin basin found in the southwest of Cameroon (Longmore and Lee, 2010; Njoh, 2018) and represents the south-eastern extension of the Niger delta in the Gulf of Guinea (Coughlin et al., 1993). The Rio del Rey basin is further limited in the north and northeast by the Precambrian Oban massif basement and Rumpi volcanics, in the northwest it is limited by the Niger Delta, in the south offshore, it is limited by the Rio muni basin in Equatorial Guinea and finally in the south-east by the Cameroon Volcanic Line (CVL) .It is located between $4^{\circ}$ and $5^{\circ}$ of latitude north and between $8^{\circ} 20^{\prime}$ and $9^{\circ} 10^{\prime}$ of longitude east (Fig. 1). Its evolutionary history is related to the opening of the South Atlantic, which began in the Upper Jurassic, following the Gondwana break-up, and ended in the Lower Cretaceous with the separation of the African and South American plates (Rabinowitz and LaBrecque, 1979). The tectono-sedimentary story of the Rio Del Rey basin began in the Lower Cretaceous (Berriasian) and comprise six geological Formations (Nely and Vaillant, 1991): a synrift Formation with continental clastics sediments; a post-rift Formation dated Albian made up by an alternation of shale and Carbonates which contains turbidites deposits (Njoh and al., 2013) and four other Formations named Kita, Akata, Agbada and Benin. The Kita and Akata Formations are made of shale associated withsome turbidites (Fig. 2). The Akata shale are under compacted. Made up by an alternation; The deposit of Agbada Formation including deltaic sand and shale over Akata Formation will give rise to a southward gravitational failure (gravity tectonic) of the two Formations (Evamy and al., 1978; Doust and Omatsola, 1990; Rensbergen and Morley, 2003). 
The reservoirs rocks in the Rio Del Rey are exclusively represented by Agbada sands and Akata turbidities. Although oil and gas discoveries were made within Akata reservoirs, all the basin production comes from Agbada sand. The Akata shales and shales inter-beds within the Agbada formation and faults constitute excellent seals. The main source rocks are represented by Akata and Agbada shale. The organic matter is essentially a mixture of types II and III Kerogen.

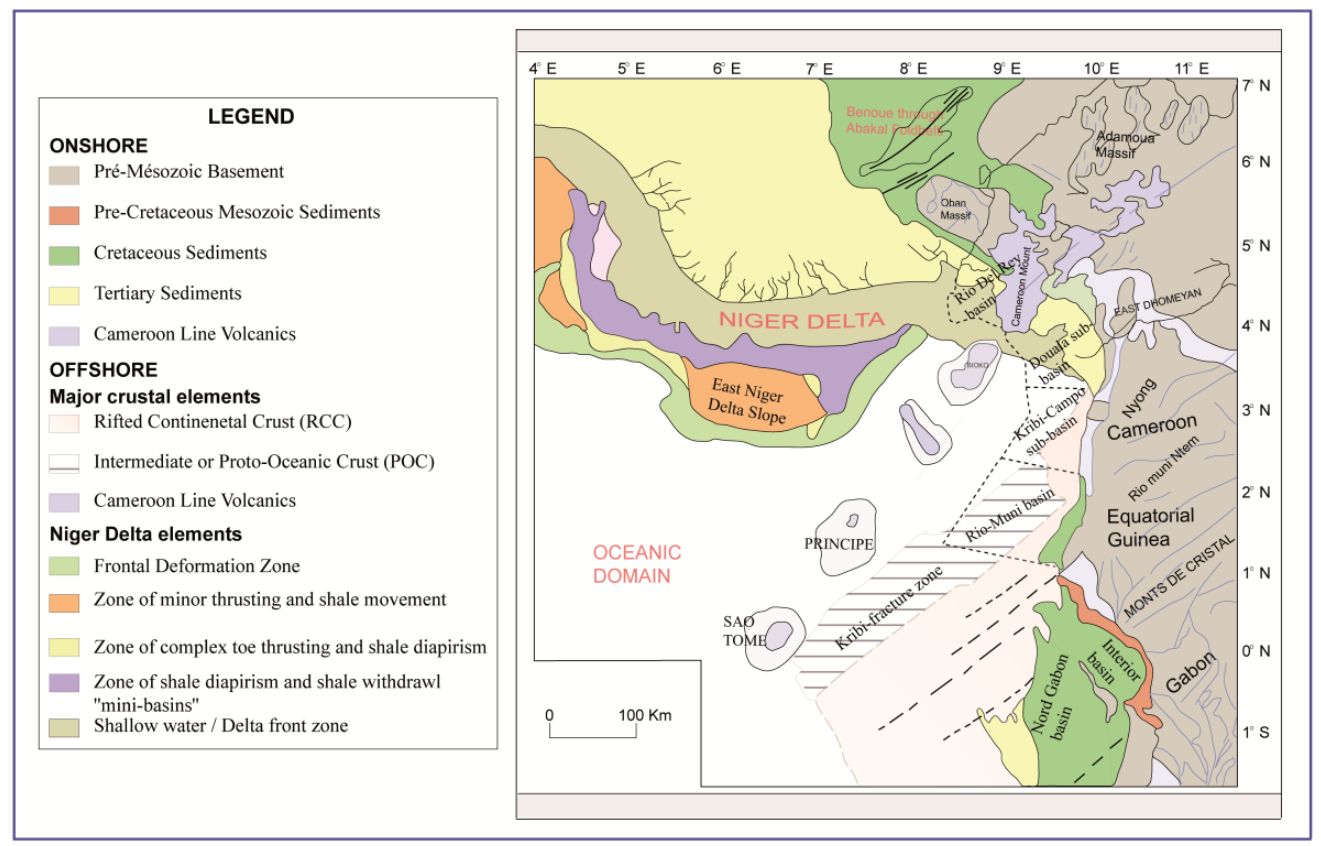

Figure 1. Geological and geographical location of Rio Del Rey basin (modified from Lawrence et al., 2002)

\section{Data and Methods}

Four coded master log and gas log were used in this study. The master log are made up by Rate of Penetration (ROP), Caliper, Gamma Ray (GR), Resistivity, Bulk Density (RHOB), Neutron Porosity (NPHI), Photo Electric Factor (PEF). The gas log contains the molecular composition of the gas sample (C1, C2, C3, Ic4, Nc4, Ic5, Nc5 in ppm unit) carried out with the Gas chromatograph. The quick-look method and gas ratio techniques were used to analyze the data: quick-look and gas ratio analyses.

\subsection{Quick-Look Method}

After verification of scales compatibility, the different logs including lithologs (GR, CAL), resistivity logs (deep and shallow) and porosity logs (RHOB, NPHI) were used. A cut-off of Gamma ray values fixed to 75 API integrated to the deflections of Caliper allowed to discriminate the shale and sand zone. The High resistivity responses were cautiously attributed as hydrocarbon zones if the NPHI curve is at the right of the RHOB curve or surimposed. The volume of shale $\left(V_{s h}\right)$ for the various reservoir zones was calculated based on the linear response (equation 1) and the Larionov (1969) equations 2 and 3 (Asquith and Krygowski, 2004) :

Linear response $\left(\mathrm{V}_{\mathrm{sh}}=\mathrm{IGR}\right)$

$$
V_{S h}=I_{G R}=\frac{G R_{\log }-G R_{\min }}{G R_{\max }-G R_{\min }}
$$

With $G R_{l o g}=\log$ reading at the depth of interest, $G R_{\min }=$ Gamma Ray value in nearby clean zone, $G R_{\max }=$ Gamma Ray value in a nearby shale

The Larionov younger rocks nonlinear responses for old and Tertiary rocks (Larionov, 1969) are:

For old rocks formation

$$
V_{s h}=0.33\left(2^{2 \times I_{G R}}-1\right)
$$

For Tertiary rocks

$$
V_{s h}=0.083\left(2^{3.7 \times I_{G R}}-1\right)
$$


The porosity $(\varnothing)$ of reservoirs was calculated from the density log using the Equations 4, 5 and 6:

$$
\emptyset_{d}=\frac{\rho_{m a}-\rho_{b}}{\rho_{m a}-\rho_{f}}
$$

Porosity of an oil bearing reservoir:

$$
\emptyset=\frac{\emptyset_{N}+\emptyset_{d}}{2}
$$

Porosity of a gas bearing reservoir:

$$
\emptyset=\frac{\emptyset_{N}+2 \emptyset_{d}}{3}
$$

With $\emptyset_{N}=$ neutron porosity, $\emptyset_{d}=$ density porosity.

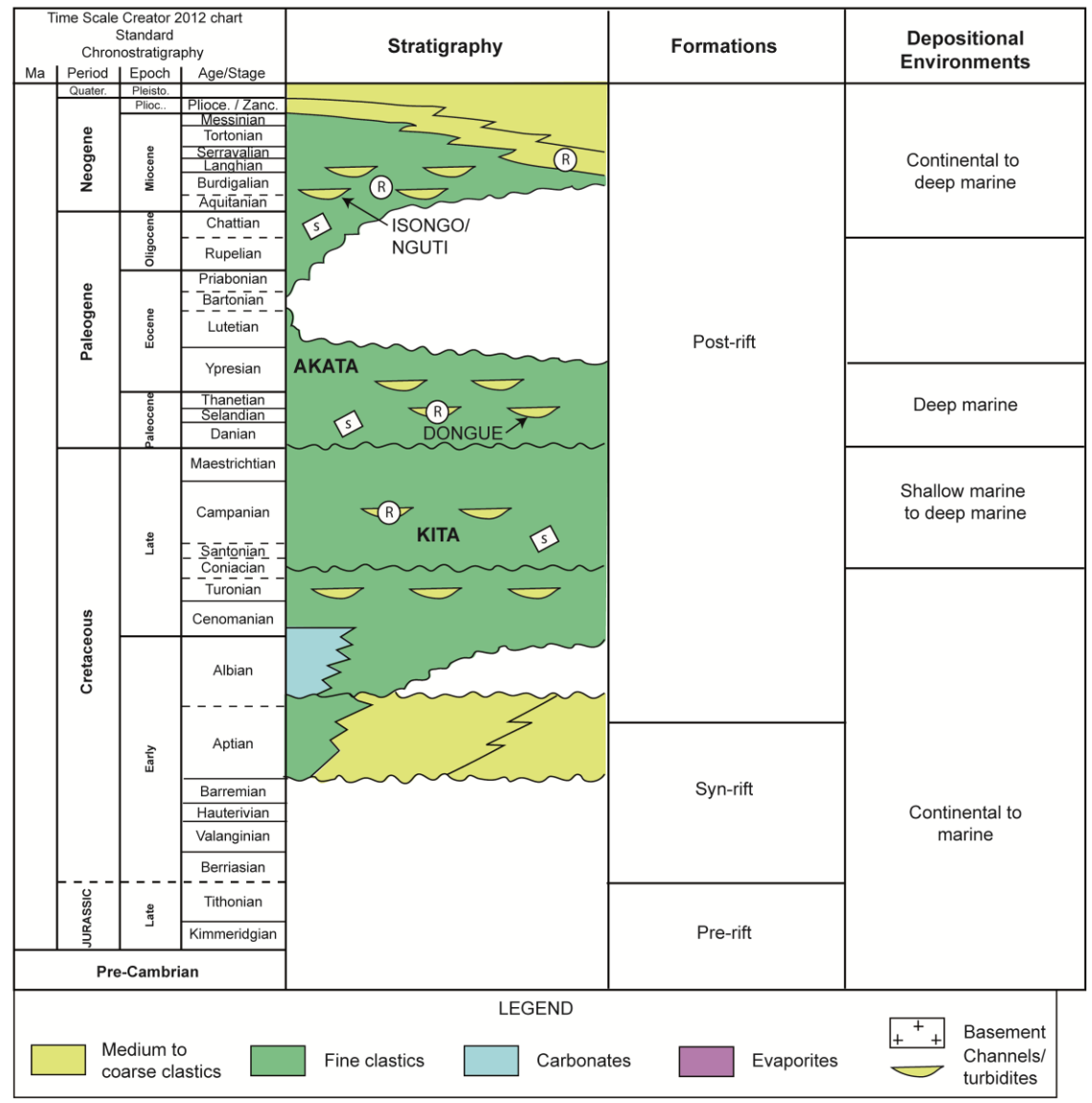

Figure 2. Rio Del Rey basin Chronostratigraphic Chart (SNH, 2015)

\subsection{Gas Ratio Analysis}

The Gas ratio analysis allow to evaluate the reservoir fluid quality and type (productivity potential) from two chromatographic techniques: gas ratio calculation and gas ratio plot. The chromatographic method is based on the calculation of several parameters such as:

- Wetness (Wh) is a measure of the amount of methane encountered; this ratio is correlated to the density. Thus when the wetness increases the density of the hydrocarbon increases. Wetness ratio $(\mathbf{W h})=[(\mathbf{C 2}+\mathbf{C 3}+\mathbf{C 4}+\mathbf{C 5}) /(\mathbf{C 1}+$ $\mathrm{C} 2+\mathrm{C3}+\mathrm{C} 4+\mathrm{C5})] \times 100$;

- Balance (Bh) is a measure of the light to heavy hydrocarbons encountered. It is inversely proportional to (Wh). Balance ratio $(\mathbf{B h})=[(\mathbf{C 1}+\mathbf{C 2}) /(\mathbf{C 3}+\mathbf{C} 4+\mathbf{C 5})]$;

- Character $(\mathrm{Ch})$ suggests the oil or gas potential, it is a comparison between $\mathrm{C} 3$ and $(\mathrm{C} 4+\mathrm{C} 5)$. Character ratio $(\mathbf{C h})=$ $[(\mathbf{C} 4+\mathrm{C} 5) / \mathrm{C} 3]$. 
These ratios are used for reservoir fluid characterization from specific tables. For the gas ratio plot technique, it consist in calculating $\mathrm{C} 1 / \mathrm{C} 2 ; \mathrm{C} 1 / \mathrm{C} 3$; $\mathrm{C} 1 / \mathrm{C} 4 ; \mathrm{C} 1 / \mathrm{C} 5$ ratios and then plot them in a logarithmic gas ratio plot to evaluate the productivity of that hydrocarbon interval(Haworth et al., 1984). Secondly, thanks to the ratio C1/C2, the hydrocarbon quality can be evaluated using the Pixler standard values (Pixler, 1985).

\section{Results and Interpretation}

This section presents the qualitative and quantitative reservoir parameters such as lithologic properties, reservoir intervals, volume shale and porosity in the well-A. The obtained results are presented as well logs responses, lithologic sections, tables and ratio plots.

\subsection{Reservoir Identification and Fluids Characterization Using Quick-Look Technique}

Four reservoirs have been identified:

- 3 porous water bearing reservoirs

- 1 porous hydrocarbon reservoir (Fig. 3) characterized by a high GR, high resistivity and PEF at the left of NPHI (Low PEF). The Quick look technique reveals that this hydrocarbon reservoir is filled by gas (NPHI at the right of RHOB with a large space between them) and oil (NPHI and RHOB are superposed) referring to the NPHI and RHOB.

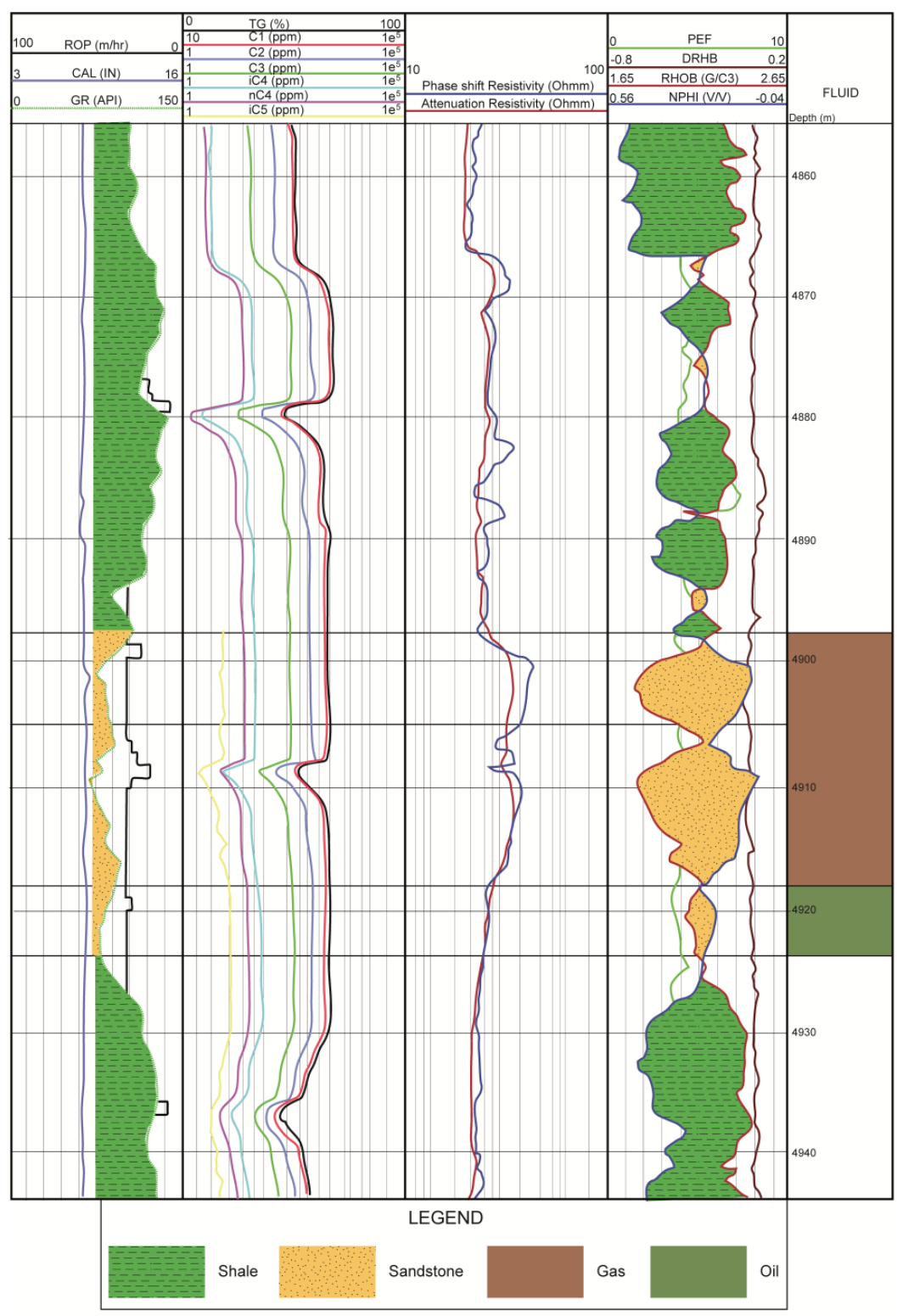

Figure 3. Quick-look analysis of A-well 4840-4940 m MD depth interval 
The four reservoir units identified in the wells included R1, R2, R3 and R4 which was delineated between 4898-4932 m (Tab 1). The high GR and low PEF observed for the reservoir R4, traduce a radioactive sandstone (with quartz mineral matrix) or an arkosic sandstone (a sandstone with high feldspar contain, feldspar is a mineral which alters and produces Kaolinite which is a shale) or a shaley sandstone. In the upper part of this reservoir, the high resistivity which entails hydrocarbon potential combined to the NPHI and RHOB cross-over it represents a gas sand. The high resistivity associated to NPHI and RHOB superposition in the lower part of the reservoir R4 represents an oil sand. The quick-look interpretation identified a radioactive sandstone filled by gas and oil which displays a GOC (Gas-Oil contact) at 3918 Mmd and with a good porosity $(0.23-0.25)$. The irregular GR log shape in the hydrocarbon bearing reservoir (R4) represents inter-bedded shale and sand. The shale volume of the R4 reservoir is equal to $43 \%$.

Table 1. Summary of average petrophysical values for well-A-reservoirs.

\begin{tabular}{|lcccccccc|}
\hline $\begin{array}{l}\text { Well-X } \\
\text { reservoir }\end{array}$ & Top & Bottom & $\begin{array}{l}\text { Gross } \\
(\mathrm{m})\end{array}$ & $\begin{array}{l}\text { Resistivity } \\
(\mathrm{ohm} . \mathrm{m})\end{array}$ & $\begin{array}{l}\text { NPHI } \\
(\mathrm{v} / \mathrm{v})\end{array}$ & $\begin{array}{c}\text { RHOB } \\
\left(\mathrm{g} / \mathrm{cm}^{3}\right)\end{array}$ & $\emptyset_{\boldsymbol{Q L}}$ & $\boldsymbol{V}_{\boldsymbol{s h}}$ \\
\hline R1 & 3582 & 1605 & 23 & 1.05 & 0.31 & 2.04 & 0.25 & 34 \\
R2 & 3830 & 3860 & 30 & 1.05 & 0.28 & 2.11 & 0.17 & 16 \\
R3 & 3882 & 1889 & 7 & 1.105 & 0.28 & 2.11 & 0.17 & 31.5 \\
R4 & 4898 & 4932 & 34 & 1105 & 0.205 & 2 & 0.23 & 43 \\
& & & & 3.4 & 0.22 & 2.11 & 0.25 & 43 \\
\hline
\end{tabular}

\subsection{Hydrocarbon Evaluation Using Gas Ratio Analysis}

The gas values were obtained using the gas log in the R4 depth intervals; the tool which sample these gas is the gas chromatograph it means that $\mathrm{C} 4=\mathrm{Ic} 4+\mathrm{Nc} 4$ and $\mathrm{C} 5=\mathrm{Ic} 5+\mathrm{Nc5}$. Before calculation of $\mathrm{Wh}, \mathrm{Bh}, \mathrm{Ch}$, the transition calculation has been done. The table 2 displays the values of Wetness, Balance and Character. The Gas ratio calculation reveals that the upper and lower part of R4 reservoir is filled by a productive gas which may be a wet gas. It can be justified by $\mathrm{Wh}<\mathrm{Bh}<100$ and $0.5<\mathrm{Wh}<17.5, \mathrm{Ch}<0.5$.

Table 2. Wetness, balance and character values of the R4 reservoir

\begin{tabular}{|lllll|}
\hline Reservoir & Depth (mMD) & Wh & Bh & Ch \\
\hline R4 & $4898-4918$ & 6.35 & 48.88 & 0.28 \\
R4 & $4918-4932$ & 7.27 & 39 & 0.33 \\
\hline
\end{tabular}

Table 3. Pixler ratio values of the R4 reservoir

\begin{tabular}{|lllll|}
\hline Reservoir/Depth (mMD) & C1/C2 & C1/C3 & C1/C4 & C1/C5 \\
\hline R4/(4898-4918) (1) & 21.5 & 60.11 & 244 & 1481.8 \\
R4/(4918-4932) (2) & 19.43 & 49.29 & 179.97 & 896.34 \\
\hline
\end{tabular}

The values of $\mathrm{C} 1 / \mathrm{C} 2, \mathrm{C} 1 / \mathrm{C} 3, \mathrm{C} 1 / \mathrm{C} 4$, and $\mathrm{C} 1 / \mathrm{C} 5$ ratio are first calculated (Table 3 ) and then plotted on the gas ratio plot to obtain 2 curves (Fig. 4): the curve (1) represents the upper part of R4 and the curve 2 represents the lower part of R4 (Fig. 4). The two curves located in the productive gas domain; which entails that the R4 reservoir is filled by a productive gas. Furthermore, the $\mathrm{C} 1 / \mathrm{C} 2$ ratios of the two parts of $\mathrm{R} 4$ reservoirs ranges between 15 and 65 ; which entails that the $\mathrm{R} 4$ reservoir is filled entirely by a productive gas. The $\mathrm{C} 1 / \mathrm{C} 4$ ratio values of the upper part of the reservoir (R4) is over 180 which indicates a non-productive gas. The $\mathrm{C} 1 / \mathrm{C} 4$ ratio values of the lower part of the reservoir (R4) ranges between 20 and 180 which indicates a productive gas. The $\mathrm{C} 1 / \mathrm{C} 2$ and $\mathrm{C} 1 / \mathrm{C} 4$ ratios of the upper part of $\mathrm{R} 4$ indicates a productive gas associated with a non-productive gas. In the lower part of $\mathrm{R} 4$ the $\mathrm{C} 1 / \mathrm{C} 2$ and $\mathrm{C} 1 / \mathrm{C} 4$ ratios indicates that we have a productive gas. The Pixler ratio plot reveals that the R4 reservoir is filled by a productive gas. 


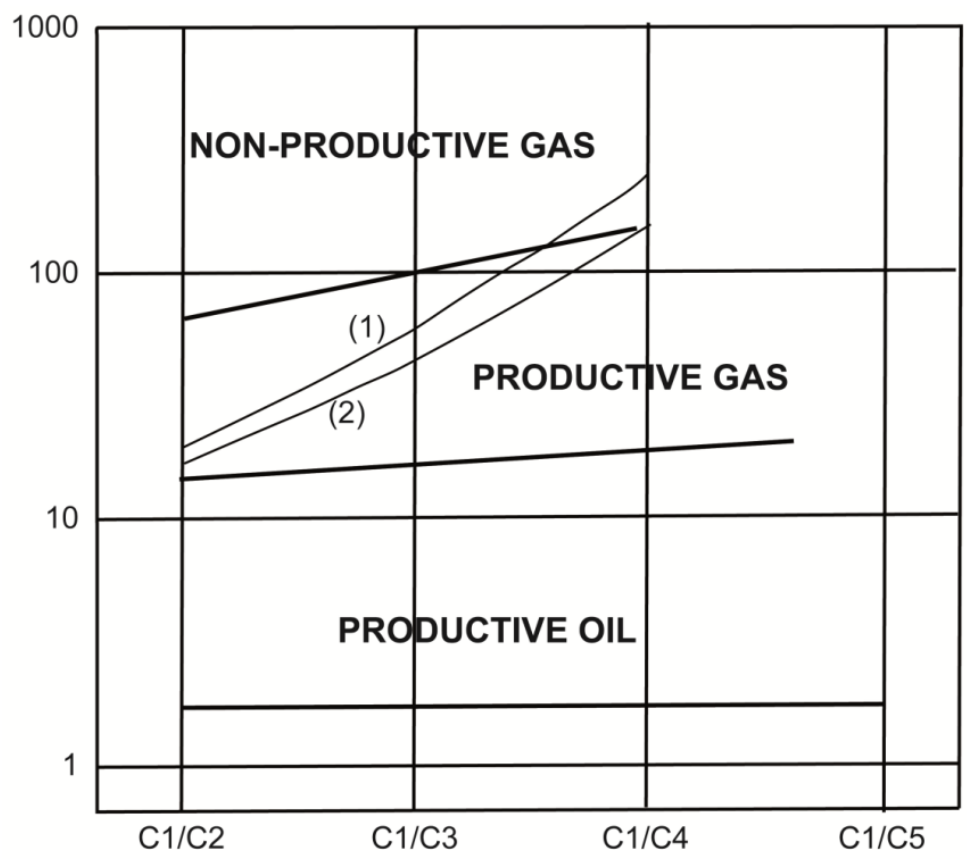

Figure 4. Gas ratio plot

\section{Discussions}

The quick-look method has highlighted a reservoir of oil and gas between 4898-4932 Mmd and which has a good porosity (0.23-0.25). The chromatographic gas ratio method indicate a reservoir filled in its upper and lower part by a productive gas which may be a wet gas. The quick-look method accurately delineated the oil and gas interval while the gas chromatographic technique was very useful in identifying the gas interval. It is known that the gas chromatography technique can't analyze liquid hydrocarbon compounds above $\mathrm{C}_{5}$ such as $\mathrm{C}_{6}, \mathrm{C}_{7}$ and $\mathrm{C}_{8}$. Its analysis is limited from $\mathrm{C}_{1}$ to $\mathrm{C}_{5}$ only. The $\mathrm{C}_{7}$ component has isomers likes $\mathrm{C}_{7} \mathrm{H}_{14}$ (methyl-cyclohexane) which is a member of the naphthenic family that is usually present in liquid phase and it is very useful in determining the presence of a liquid phase. The gas chromatography (gas chromatograph) has analyzed $\mathrm{C}_{1}$ to $\mathrm{C}_{5}$ and found that the fluid was light (Bh>Wh) fluid (eg. Gas). But a fluid may be relatively light in the $\mathrm{C}_{1}$ to $\mathrm{C}_{5}$ range but with a proportionally higher abundance of $\mathrm{C}_{7} \mathrm{H} 14$ suggesting a liquid phase. From $\mathrm{C}_{1}$ to $\mathrm{C}_{5}$ components, the $\mathrm{Wh}, \mathrm{Bh}$, and $\mathrm{Ch}$ ratios traduces a light fluid (gas) and from $\mathrm{C}_{1}$ to $\mathrm{C}_{7}$ (which is carryout by the FLAIR gas analyses) the ratios detect the presence of a liquid phase $(\mathrm{Bh}<\mathrm{Wh})$. The incapacity of gas chromatography to detect and analyze the $\mathrm{C}_{7} \mathrm{H}_{14}$ or heavy hydrocarbons in general may be the reason of this false result. Finally, the chromatographic gas ratio analysis reveals that the entire reservoir is filled by a productive gas which may be a wet gas. The gas ratio analysis provide an accurate interpretation in gas. In natural gas the chemical components range from $\mathrm{C}_{1}$ until $\mathrm{C}_{5}$, and the gas ratio analysis is based only on $\mathrm{C}_{1}$ to $\mathrm{C}_{5}$ components that is why it accuracy is very good in gas. But in oil the gas ratio analysis is not accurate because in oil the components involve from $\mathrm{C}_{1}$ until $\mathrm{C}_{7}$ sometimes until $\mathrm{C}_{8}$.

\section{Conclusion}

The major problem encountered during this work was the difficulty to provide an interpretation to results obtained after using quick-look and chromatographic gas ratio analysis which were not correlable. The false result provided by the chromatographic gas ratio analysis helped us to understand well the limitation of gas chromatography in hydrocarbon characterization. Gas chromatography is accurate in a gas zone but not accurate in oil zone. Finally, we identified a turbidity characterized by interbedding of sand and shale which is filled by a productive wet gas and oil and which may be deposited in the basin plain (deep sea).

\section{Acknowledgement}

Part of this work was carried out in ADDAX Petroleum and in University of Douala in the framework of the Master thesis of Mopa Moulaye Ahmed Salim

\section{References}

Asquith, G., Krygowski, D., Henderson, S., \& Hurley, N. (2004). Basic well log analysis: AAPG methods in exploration series 16. Published by The American Association of Petroleum Geologists Tulsa, Oklahoma, 244p. https://doi.org/10.1306/Mth16823 
Coughlin, R. M., Bement, W. O., \& Maloney, W. V. (1993). Petroleum geology of the deltaic sequence, Rio Del Rey basin, offshore Cameroon. AAPG Bulletin (American Association of Petroleum Geologists);(United States) , 77 (CONF-9310237--). https://doi.org/10.1306/BDFF7F34-1718-11D7-8645000102C1865D

Doust, H., \& Omatsola, E. (1990). Niger Delta divergent/passive margin. American Association of Petroleum geologist bulletin memoir, 48, 201-238.

Evamy, B. D., Haremboure, J., Kamerling, P., Knaap, W. A., Malloy, F. A., \& Rowlands, P. H. (1978). Hydrocarbon habitat of tertiary Niger Delta. American Association of Petroleum Geologists bulletin, 62, 1-39. https://doi.org/10.1306/C1EA47ED-16C9-11D7-8645000102C1865D

Haworth, J. H., Sellens, M., \& Whittaker, A. (1985). Interpretation of hydrocarbon shows using light hydrocarbons gases from mud-log data. AAPG bulletin 69. https://doi.org/10.1306/AD462BDC-16F7-11D7-8645000102C1865D

Kabbabe, T. (2008). Stratigraphic and sedimentology controls on reservoir properties of the S.9-S.7 sands (Upper Miocene) in the Lima block of the Mokoko-Abana field (Rio Del Rey basin, offshore Cameroon). Africa Geosciences Review, Special Publication, 01\&02, 1-12.

Lawrence, S. R., Munday, S., \& Bray, R., (2002). Regional geology and geophysics of the eastern gulf of guinea (Niger Delta to Rio Muni). Lead Edge, 21, 112-117. https://doi.org/10.1190/1.1523752

Longmore, J., \& Lee, J., (2010). Africa oil and gas source: Hydrocarbon leakage interpretation on seismic data. Mart Pet Geol, 26(7), 1304-1319. https://doi.org/10.1016/j.marpetgeo.2008.09.008

Nelly, G., \& Vaillant, L. (1991). Cameroon regional geology: Geodynamic interpretation of a Rio Del Rey cross section North-South, Elf Serepca docs, p18.

Njoh, O. A., Bassey, E. A., Amma, J. E., \& Agbor, V. W. (2013). Palynostratigraphy of early cretaceous sedimentary deposits from the Rio Del Rey basin south west Cameroon. Journal of the Cameroon academy of science, 11, 51-61.

Noudjo, D. A. L., Mvondo, O. F., Ntamak-Nida, M. J., Belinga, R., Koum, S., \& Guillocheau, F. (2018). Offshore stratigraphic architecture of the Miocene to Actual deposits in the southernb margin of Rio Del Rey (South Cameroon). American Scientific Research Journal for Engineering, Technology, and Sciences, 46(1), 189-217.

Pixler, B. O. (1969). Formation evaluation by analysis of hydrocarbon ratios. Journal of Petroleum Technology , 21 (06), 665-670. https://doi.org/10.2118/2254-PA

Rabinowitz, P. D., \& Labrecque, J. (1979). The Mesozoic South Atlantic Ocean and evolution of its continental margins. Journal of Geophysics Research, 84, 5973-6002. https://doi.org/10.1029/JB084iB11p05973

SNH. (2015). Blocks on offer in the Rio Del Rey basin, DKC and Mamfe basin, 1-16.

Van Rensbergen, P., \& Morley, C. K. (2003). Re-evaluation of mobile shale occurences on seismic section of the champion and Baram deltas. Geological society of London special publication, 216, 395-409. https://doi.org/10.1144/GSL.SP.2003.216.01.26

\section{Copyrights}

Copyright for this article is retained by the author(s), with first publication rights granted to the journal.

This is an open-access article distributed under the terms and conditions of the Creative Commons Attribution license (http://creativecommons.org/licenses/by/4.0/). 